\title{
IN SEARCH OF EMPIRICAL EVIDENCE THAT LINKS RENT AND USER COST
}

Dixie M. Blackley

James R. Follain

Working Paper No. 5177

\section{NATIONAL BUREAU OF ECONOMIC RESEARCH \\ 1050 Massachusetts Avenue \\ Cambridge, MA 02138 \\ July 1995}

This paper was prepared for an NBER Conference on Public Policy and Housing held on October 20-22, 1994. Helpful comments were provided by James Alm, Ann Dougherty, Donald Dutkowsky, Gyan Sinha, Michelle White, and other participants at the NBER Conference. We are particularly grateful to Patric Hendershott for his comments; they have greatly improved the clarity of our presentation. Nelson Wong provided valuable research assistance. This paper was prepared as part of the NBER Study on Housing Dynamics and was presented at the NBER Study Conference. Any opinions expressed are those of the authors and not those of the National Bureau of Economic Research.

() 1995 by Dixie M. Blackley and James R. Follain. All rights reserved. Short sections of text, not to exceed two paragraphs, may be quoted without explicit permission provided that full credit, including $\odot$ notice, is given to the source. 


\title{
IN SEARCH OF EMPIRICAL EVIDENCE \\ THAT LINKS RENT AND USER COST
}

\begin{abstract}
Most models of the rental housing market assume a close linkage between the level of residential rents and the after-tax user cost of rental housing capital. However, little empirical evidence exists to establish the strength of this linkage or the speed with which rents adjust to changes in user cost or tax policy. This paper develops and estimates an econometric model of the rental housing market in order to shed light on both of these issues. United States annual data for 1964 through 1993 are used to generate two-stage least squares estimates of a four equation structural model.

Although the results are generally consistent with expectations and reveal several interesting relationships among the system variables, the estimates fail to identify a strong relationship between rent and user cost. About half of an increase in user cost is ultimately passed along as higher rent. The adjustment process also takes a long time, with only about a third of the long-run effect realized within ten years of a user cost shock. The fundamental reason for this result is that our estimate of the user cost series, based upon widely accepted procedures, is much more volatile than the residential rent series.
\end{abstract}

Dixie M. Blackley

Department of Economics

Le Moyne College

Syracuse, NY 13214
James R. Follain

Center for Policy Research

447 Eggers Hall

Syracuse University

Syracuse, NY 13244-1090 


\section{Introduction}

Changes in long-run equilibrium residential rents are widely believed to be driven by changes in the real after-tax cost of capital used to produce rental housing. A corollary to this belief is that changes in the tax treatment of rental housing generate changes in the level of rents. However, little empirical evidence currently exists to support these beliefs, and even less is known about the speed with which rents adjust to changes in user cost or tax policy.

The magnitude and speed of the response of rent to changes in the cost of capital determine the beneficiaries of tax policy toward rental housing. If rent levels adjust slowly or less than completely to changes in user cost triggered by tax policy changes, then large changes in the asset price of rental housing can result. In this case, tenants will be little affected and property owners will experience large windfall gains or losses. For example, more generous depreciation rules will generate windfall gains for property owners, but tenant benefits will be minimal or long delayed. If instead rent levels adjust quickly and completely to changes in user cost triggered by tax policy changes, then the bulk of the benefits or costs of these changes will accrue to tenants; property owners will be little affected. Alm and Follain (1994) develop a theoretical basis for empirical work on these questions. Their central message is that the linkage between user cost and rent depends upon the structure of the rental housing market. A four equation discrete dynamic model is developed and estimated to explore the linkage. The model consists of a demand equation for housing, an accounting identity that monitors the size of the housing stock, a construction equation, and an asset price equation. This last equation is the key to the analysis and posits that the asset price of housing equals replacement cost plus the sum of the future or expected gap between rent in period $t+i$ and user cost. They also consider 
various specifications of household expectations about future movements in market rent. Their simulations demonstrate the factors that affect the speed with which rents adjust, but the parameterization of the simulation model is not supported by empirical evidence.

Hendershott, Follain and Ling (HFL) (1987) and Follain, Hendershott and Ling (FHL) (1987) consider the first question in simulation analysis of the rental housing market. They focus primarily on the impact of the 1986 Tax Reform Act (TRA) upon long-run equilibrium rents, but they also consider its effects upon asset prices using rather ad hoc assumptions about the speed at which rents adjust to user cost. Ling's recent simulation analysis (1992) extends the HFL approach. None of this work was designed to provide empirical evidence to support the parameterization of the model, especially the speed with which rents adjust to long-run equilibrium.

Follain, Leavens and Velz (FLV) (1993) shed light on both questions by examining the empirical relationship between rent and user cost. They estimate a reduced form model of the rental housing market using pooled time-series and cross-section data at the metropolitan level; data limitations prohibit estimation of the exact structural model suggested by Alm and Follain. FLV find that changes in user cost significantly affect construction, but not the level of rents. Coupled with casual inspection of the data and the number of specifications considered, they suggest that if a strong relationship does exist, it is a subtle one that will not be easily uncovered.

DiPasquale and Wheaton (1992) offer the most comprehensive empirical analysis to date of the linkage between rent and user cost. They estimate a two equation model of the demand for rental housing and the construction of multifamily units using U.S. annual data for 1964 
through 1989. Their estimates suggest that rents rise modestly in response to an increase in user cost.

This paper seeks to develop and estimate an econometric model of the rental housing market. The basic elements of the model draw upon the papers noted above, especially AlmFollain and DiPasquale-Wheaton. Like both papers, the model emphasizes the structural equations underlying the rental housing market and the dynamic characteristics of the housing market as it adjusts to long-run equilibrium values. Unlike both papers, it attempts to model both the demand for rental housing services and the demand for rental housing units. Alm-Follain model only the demand for housing services, while DiPasquale-Wheaton model only the demand for housing units.

The next section presents an econometric model of the rental housing market and discusses its underlying theoretical framework. The data used to estimate the model are described in the third section. Section IV presents and evaluates the empirical results, and Section $\mathrm{V}$ highlights the important conclusions of the analysis.

\section{Model specification}

The econometric model is derived from a larger and more detailed structural framework. This structural model is represented by a six-equation system of linear simultaneous equations. The endogenous variables are the demand for rental housing per household, the number of renter households, the aggregate supply of rental housing, construction, the asset price of rental housing, and market rents. 
The demand side of the rental housing market includes equations representing the demand per household and the number of renter households. The demand for rental housing services per household $\left(q_{t}\right)$ in period $t$ depends upon the real rental price $\left(p r_{t}\right)$ per unit of constant quality rental housing and the permanent income $\left(Y P_{t}\right)$ of a typical renter household:

$$
q_{t}=f\left(p r_{t}, Y P_{t}\right)
$$

Standard consumer theory suggests housing demand varies inversely with rental price and directly with income. Tenure choice is reflected in the renter households equation. The number of renter households $\left(N R_{t}\right)$ depends upon the relative price of rental and owner-occupied housing ( $\left.p r_{t} / p o_{t}\right)$, the permanent income of a typical household, and the size of the adult population $\left(P O P_{t}\right)$ :

$$
N R_{t}=f\left(p r_{t} / p o_{t}, Y P_{t}, P O P_{t}\right)
$$

The price of owner-occupied housing is defined as the product of the owner user cost rate $\left(u c o_{t}\right)$ and the asset price of a comparable owner-occupied house $\left(P O_{t}\right)$; that is, $p o_{t}=u c o_{t} P O_{t}$. Increases in the relative price of renting or household income will encourage home ownership and reduce the demand for rental dwellings. Assuming demand per household is typical of renter households generally, the aggregate demand for rental housing services $\left(Q D_{t}\right)$ is the product of housing services demanded per renter household from (1) and the number of renter households from (2), or $Q D_{t}=q N R_{t}$.

The supply side of the rental housing market includes equations for aggregate supply and construction. Each period's aggregate supply $\left(Q S_{t}\right)$ of rental housing equals last period's aggregate supply, net of depreciation, plus this period's construction $\left(C_{\mathrm{t}}\right):^{1}$ 


$$
Q S_{t}=(1-d) Q S_{t-1}+C_{t},
$$

where $d$ equals the housing depreciation rate. Construction in period $t$ depends upon profit opportunities as reflected in the difference between asset price $\left(P R_{t}\right)$ and replacement $\operatorname{cost}\left(P R C_{t}\right)$ :

$$
C_{t}=\alpha\left(P R_{t}-P R C_{t}\right),
$$

where $\alpha$ reflects the responsiveness of construction to the gap between asset price and replacement cost. ${ }^{2}$ Replacement cost refers to the cost of building a unit of housing plus the value of the land on which it is placed. This is a traditional Tobin's q response.

The asset price of rental housing each period equals the discounted value of the future expected "net income" of rental housing each period. With net income equal to rent less depreciation and an interest rate $r$, the current period asset price is given by:

$$
P R_{t}=\sum_{i=0}^{\infty}\left[E\left(p r_{t+i}-d P R C_{t-1+i}\right) /(1+r)^{i}\right] .
$$

The asset price adjusts each period in response to changes in expected future net income and the current market rate of interest.

Many have analyzed the characteristics of models similar to this one. Alm and Follain analyze a model similar to equations (1), (3), (4), and (5). They use different assumptions regarding the manner in which expectations are formed and the extent to which the market clears each period. If markets are assumed to clear completely each period, they show that the asset price equals replacement cost; that is, $P R_{t}=P R_{t}$ in long-run equilibrium. They further show that current period rent equals the product of the user cost rate $\left(u c r_{t}\right)$ and the current asset price; that is, $p r_{t}=u c r_{t} P R_{t}$ in each period. Furthermore, the rental price converges to the user cost of rental housing capital; that is, $p r_{t}=u c r_{t} P R C_{t}$ in long-run equilibrium. In their particular model, $u c r_{t}$ is simply $(r+d)$. In a more general model and in the empirical work that follows, the user 
cost rate is defined to include a much larger set of factors such as the tax treatment of investments in rental real estate.

The final equation in the system recognizes that the rental housing market may adjust gradually to changes in the exogenous variables that drive it. This process is similar to those used in the empirical work of DiPasquale-Wheaton and Hendershott and analyzed numerically by Alm-Follain. Movements in rental price are posited to respond to two factors. The first is excess aggregate supply and the second is the gap between rent and user cost. Assuming a loglinear relationship among these variables:

$$
\ln \left(p r_{t} / p r_{t-1}\right)=\phi_{1} \ln (p r / u c r P R C)_{t-1}+\phi_{2} \ln (Q S / Q D)_{t-1},
$$

where $\phi_{1}$ and $\phi_{2}$ measure the responsiveness of rental price to lagged values of the rent user cost gap and of excess supply. Both coefficients are expected to be negative. A negative value for $\phi_{1}$ ensures that rent moves toward user cost in long-run equilibrium. Similarly, a negative value for $\phi_{2}$ reflects the difficulty of raising rent during periods of excess supply.

This specification of the rent adjustment equation introduces some interesting possibilities into the standard user cost model. If rent equals user cost in long-run equilibrium and if excess supply is zero, then this equation predicts that the real price of housing is constant in long-run equilibrium. This is consistent with the standard user cost model in which rent equals user cost in long-run equilibrium. If excess supply is positive in long-run equilibrium, as may occur in a model with a natural vacancy rate, then either real rents will increase at a positive rate or the rent to user cost ratio must be less than one. ${ }^{3}$

This six-equation system is modified in three major ways to obtain the econometric model for estimation. First, a proxy for the current asset price is needed in the empirical analysis 
because a price series is unavailable. We use the gap between the current level of rents and the user cost of capital as a proxy for the gap between the current asset price and replacement cost. The crudeness of this proxy should be considered when assessing the performance of the supply equation because the rejection of a strong relationship between the supply of housing and the rent to user cost gap is actually a test of two separate hypotheses, one involving the user cost model and one involving the rent adjustment process.

Second, the supply equation is also modified to include the lagged excess supply [(QS $\left.Q D)_{t-1}\right]$. This implies that builders may respond not only to the rent to user cost gap, but also to the quantity gap. This could arise because prospective developers are just as hampered by the lack of information about current asset prices as are builders of econometric models. As such, they may use an easier to obtain measure of the tightness of a housing market, like vacancies. In a units oriented model like DiPasquale-Wheaton, the vacancy rate serves this role directly.

Third, household decisions regarding the consumption of housing and tenure choice are unlikely to respond instantaneously to changes in market conditions due, for example, to the transactions costs associated with moving. Like many previous studies, we address this by specifying both the services and units demand equations in partial adjustment form. This approach allows both short-run and long-run elasticities to be estimated for these equations.

\section{Model Summary}

Assuming log-linear functional forms and incorporating these modifications yield the following specification of the econometric model to be estimated: 
(i)

Demand Per Household

$$
\ln \left(q_{t}\right)=\alpha_{0}-\alpha_{1} \ln \left(p r_{t}\right)+\alpha_{2} \ln \left(Y P_{t}\right)+\alpha_{3} \ln \left(q_{t-1}\right)
$$

(ii) Number of Renter Households

$$
\ln \left(N R_{t}\right)=\gamma_{0}-\gamma_{1}\left[\ln \left(p r_{t}\right)-\ln \left(u c o P O_{t}\right)\right]-\gamma_{2} \ln \left(Y P_{t}\right)+\gamma_{3} \ln \left(P O P_{t}\right)+\gamma_{4} \ln \left(N R_{t-1}\right)
$$

(iii) Aggregate Supply Equation

$$
\ln \left(Q S_{t}\right)=\beta_{0}+\beta_{1}\left[\ln \left(p r_{t}\right)-\ln \left(u c r_{r} P R C_{f}\right)\right]-\beta_{2}[\ln (Q S)-\ln (Q D)]_{t-1}+\beta_{3} \ln \left(Q S_{t-1}\right)
$$

(iv) Rent Adjustment

$$
\ln \left(p r_{p}\right)-\ln \left(p r_{t-1}\right)=-\delta_{2}[\ln (p r)-\ln (u c r P R C)]_{t-1}-\delta_{3}[\ln (Q S)-\ln (Q D)]_{t-1}
$$

All slope coefficients are positive, so the anticipated effects of the explanatory variables are incorporated in this summary. It also incorporates coefficient restrictions implied by the underlying theoretical model. The most important of these restricts current rental price and rental user cost to have equal but opposite effects on supply.

\section{Data Description}

There are two broad data options for estimating the linkage between rent and user cost in the context of a structural model of the rental housing market. One uses panel data at the metropolitan level; the other uses aggregate data for the United States. Our approach uses United States aggregate annual data from 1964 through 1993. There are advantages and disadvantages to using these data. The main advantage is the availability of national aggregate series to measure every variable in the structural model except the asset price of rental housing. This is particularly valuable because it allows a distinction between the quantity of housing services 
consumed per household and the number of households; this is not easily done at the metropolitan level because consistent and frequent time series data on the value of the housing stock are not available. Data on the current asset price are not available at either the national or the metropolitan level; therefore, a proxy for this series is required for both options. 5 The main disadvantage is the limited number of available observations, which is a problem that plagues most macroeconomic studies. Furthermore, these data aggregate over a wide variety of local housing markets that respond in different ways to nationally triggered shocks. Despite these disadvantages, we believe it is reasonable to use these data to address the questions posed in this study. If a strong linkage between rent and user cost is identified, then the finding would constitute evidence of the user cost model and the power of tax policy to affect rents. Conversely, failure to identify a strong linkage would not necessarily reject the model because the failure may be attributable to deficiencies in the data.

Summary statistics are presented in Table 1 for all variables used in the estimation. The data are obtained primarily from the CitiCorp data base and the Department of Commerce. The definitions of the supply and demand for rental housing distinguish our approach from some other studies of the rental housing market, in particular, DiPasquale and Wheaton (1992). Our approach seeks to incorporate both units and services concepts. The aggregate supply of rental housing stock (QS) is the Department of Commerce's series for the constant cost value of the net stock of privately owned tenant-occupied housing [Musgrave (1993), Table 12]. ${ }^{\complement}$ Changes in this stock series represent new construction or new investment in rental housing.

Multifamily starts are also frequently employed as a measure of investment in rental housing. We prefer the stock series because it represents rental housing specifically and, in 
theory, allows a distinction to be made between the number of new housing units and the services provided by these units. The multifamily starts series includes some units destined to be owneroccupied and omits single family rental housing units, improvement expenditures for rental housing, and conversions in occupancy status. Figure 1 presents an investment series based on the Commerce data and the multi-family starts series. Although the series are highly correlated, discrepancies occur in the early 1970s, the late 1970s, and the early 1990s. Identifying the reasons for these discrepancies is a difficult task, but they do seem to lend support to our preference for the stock series, which, in theory, provides appropriate measures of aggregate supply and investment in rental housing.

The aggregate demand for rental housing is the occupied rental housing stock $(Q D)$, defined as aggregate supply multiplied by one minus the rental vacancy rate. The Census H-111 series on vacancy rates is used to measure the rental housing vacancy rate. This may understate demand because vacant units are probably below the average value of all rental housing units, but we uncovered no data or method by which to incorporate this into the demand series.

The aggregate demand for rental housing may also be viewed as the product of the quantity of housing services generated by the average occupied rental housing unit and the total number of occupied rental housing units. The number of renter households (NR) equals the total number of households multiplied by one minus the home ownership rate. The latter two series are obtained from the Census. The demand per renter household (q) equals aggregate demand divided by the number of renter households (QD/NR). Indexes of the two components of rental housing demand are presented in Figure 2. Per household demand rises relatively quickly until 
the late 1970s, falls briefly, and then levels off. The number of renter households grows at about 2.3 percent per year, although its growth was well above this average during most of the $1980 \mathrm{~s}$.

Excess supply is defined as the difference between aggregate supply and aggregate demand. The excess supply series in millions of dollars and the vacancy rate are plotted in Figure 3. Since the vacancy rate is used to derive the demand series, excess supply tracts the vacancy rate closely. Both series show the substantial rise in excess supply during the middle and late 1980s. In dollar terms, the amount of the excess supply totals nearly $\$ 90$ billion dollars. As may be expected, this large overhang of excess capacity has a dampening effect upon the current status and near-term future of the market for new rental housing.

The rental price $(p r)$ of rental housing plays an important role in the model presented in the previous section. This measure is generated by modifying the residential rent component of the Consumer Price Index in three ways. First, the index is adjusted upward by 0.5 percent per year to offset a downward bias in the index due to its likely underestimation of depreciation. This bias arises because the rent index is based upon the average rent among a sample of existing properties. As such changes in the average rent among this sample is likely to understate movements in the market price of rental housing. Second, the series is converted to a real rent series using the GDP deflator. Third, the index is applied to the average value of a rental unit in 1964.

A critical variable in this analysis is rental user cost. Our approach follows closely that used by HFL, FHL, and Follain and Ling. In essence, a multiperiod present value model is used to compute the first period rent that sets the net present value of the project equal to zero. The cash flows of the project include rent less operating expenses, real appreciation less physical 
depreciation of the project, tax benefits, and other costs associated with the construction and sale of the unit. The principle difference between our series and the others deal with the complexities of computing user cost for an annual time series. The other work focuses on one or two time periods.

One key component of the user cost calculations is the expected inflation series. We use quarterly data to estimate an adaptive expectations model in which the current value of the GDP deflator is regressed on four lags. Expected inflation is a three year moving average of the quarterly predicted values of the GDP deflator. We investigated various versions of this approach and chose this one because it is both reasonable and less likely to generate sharp and short-lived spikes in expected inflation.

The cash flows of the project do not include payments on a mortgage. The discount rate is an after-tax discount rate that represents a weighted average cost of capital. As discussed by FHL, this is done to eliminate the need to continuously update the optimal debt to equity ratio and to remain consistent with the corporate finance approach to capital budgeting. The discount rate $(r)$ is:

$$
i e r=(1-m t r r) i d[1+(1-m t r p r) m r p]
$$

where mtrr and mtrpr are the marginal tax rates of the investor for ordinary income and equity income, respectively. These may differ because of the tax treatment of capital gains. The nominal interest rate id is represented by the ten-year Treasury rate and mrp is a risk premium. The only difference between this discount rate and FHL's is that the risk premium is proportional rather than additive to the nominal discount rate, which seems appropriate in a time series context. 
Several parameters must be assigned to complete the present value calculations. Some are invariant to the tax regime, including the property tax rate $(0.02)$, the sales commission rate (0.06), and the land to property value ratio (0.85). Several others vary by tax regime. The marginal tax rate of the investor in rental property equals 0.50 prior to $1982,0.45$ for 1982 through 1986, and 0.36 after 1986 . The capital gains tax rate equals 0.5 prior to $1978,0.4$ for 1978 through 1986, and 1 after 1986. The useful life of a property for tax purposes equals 30 years prior to 1982,15 years for $1982-83,18$ years for 1984,19 years for $1985-86$, and 27.5 years since 1987. The method of depreciation is 200 percent of straight line until 1982,175 percent for 1982-86, and straight line since 1987. The optimal determination of whether to use the accelerated or straight line method is taken into account. The holding period for rental property investments is allowed to vary among tax regimes. With two exceptions, the holding period is set equal to the useful tax life of the property, which is a result that is produced by simulations in which the holding period is chosen as the one that minimizes user cost. The two exceptions pertain to the $1964-68$ period when the optimal holding period is 12 years and the 1982-86 period in which we allow for multiple trading. Otherwise, only one trade is allowed because multiple trading, or churning, has little impact on the size of user cost. FHL explain the reasoning underlying this approach in more detail.

User cost and rent expressed in real dollars are plotted in Figures 4 and 5 . Figure 4 also includes the user cost rate in percent. Several aspects of these patterns are noteworthy. The user cost series in real dollars and as a rate are quite comparable. The user cost rate fluctuates around 6 and 7 percent until the latter part of the 1970s when it declines substantially. This is probably a response to an increase in expected inflation and a less than full adjustment of nominal interest 
rates to it. The rapid rise in the early 1980 s is due primarily to higher interest rates and lower inflationary expectations, and occurred despite generous tax policy. FHL and others have noted and discussed this previously. A sharp rise in user cost occurs in 1987 because of TRA, but user cost has declined since then due to the general decline in real interest rates.

The most important point to note about these series is the relative volatility of rent and user cost. Rent is a stable, slow-moving series compared to user cost. This pattern portends a result that emerges from the econometric investigation below. Such disparities in the volatility of the rent and user cost series make it difficult to identify a strong linkage between rent and user cost.

The expression for the cost of owner-occupied housing is the product of the user cost rate for owner-occupied housing and the current asset price of owner-occupied. The definition of the user cost rate for owner-occupied housing is the one used by HFL and Follain and Ling (1988). The user cost rate is the amount of first period rent per dollar of housing stock that makes the net present value of the stream of services, payments, and costs associated with home ownership equal to zero. The calculations are similar but less complicated than the ones used to compute the rental user cost rate because the tax treatment of owner-occupied housing is simpler. The two main differences are the discount rate, which equals 90 percent of the investor's discount rate, and the tax rate of the marginal home owner, which equals the Barro and Sahasakul (1984) series prior to 1987 and 0.25 thereafter. The current asset price of owneroccupied is measured by the price deflator used by the Commerce Department to compute the real value of the tenant-occupied housing stock. 9 
Three other variables are used in the estimation of the model. Consumption expenditures per household converted to real dollars by the GDP deflator serve as a proxy for permanent income $(Y P)$. The U.S. population age 16 and over measures adult population (POP). Replacement cost $(P R C)$ equals the national Boeckh construction cost index for apartments.

\section{Estimation Procedure and Results}

Several variations of the structural model summarized in Section II are evaluated. The demand per household, the number of renter households, and the rent adjustment equations generally perform well. The major exception to the theory underlying the structural model occurs in the supply equation. The problem is that the rent to user cost gap is never significant and often has a sign counter to the underlying theory. Relaxing the coefficient restrictions on rent and user cost does not solve this problem. The rent coefficient is positive as expected, but the user cost coefficient has a positive sign rather than the anticipated negative sign and is always insignificant. The result is obtained despite using different functional forms and different regressors. In light of this inconsistency, the final estimates reported in Table 2 omit the rent to user cost gap from the supply equation.

\section{Estimation Procedure}

The econometric model summarized in Section II is a four equation simultaneous system. Parameter estimates are generated using Two stage least squares (2SLS) with a modification described in Kmenta (1986) to account for the presence of lagged endogenous variables among the regressors. The procedure treats lagged endogenous variables as if they are current 
endogenous variables and uses current and lagged purely exogenous variables as instruments in 2SLS. This approach generates consistent 2SLS parameter estimates when lagged endogenous variables are among the regressors.

The further issue of autocorrelation is addressed by Greene (1993), Fair (1970), and others who offer procedures for estimating simultaneous equation models with lagged endogenous variables and serially correlated errors. This approach involves two steps. First, appropriate tests are conducted to identify the presence of autocorrelation [Greene (1993)]. The lagged dependent variable appears directly in the demand per household and renter households equations. In the supply equation, lagged housing stock appears itself as an explanatory variable and also in the excess supply variable. Thus, the effective coefficient on lagged housing stock is the sum of the coefficients on $\ln (Q S)_{-1}$ and $[\ln (Q S)-\ln (Q D)]_{-1}$. Similarly, in the rent adjustment equation, the effective coefficient on lagged rental price is the sum of the coefficients on $\ln (p r)_{-1}$ and $[\ln (p r)-$ $\ln (u c r P R C)]_{-1}$. Durbin's $\mathrm{h}$ test indicates that autocorrelation exists in the demand per household equation, but not the renter households or rent adjustment equations. ${ }^{1} \mathbb{C}$ Durbin's $\mathrm{h}$-statistic cannot be computed for the supply equation because the product of the sample size and the estimated variance of the lagged housing stock coefficient exceeds one. Instead, an alternative test is used where the current residual is regressed on the lagged residual along with the structural equation's explanatory variables. If the coefficient on the lagged residual is significant, then autocorrelation is present. This alternative test indicates the presence of autocorrelation in the supply equation. ${ }^{12}$ Second, assuming an AR(1) error structure, the iterative Prais-Winsten method for computing autocorrelation coefficients is used within an autoregressive 2SLS procedure. The converged 
autocorrelation coefficient equals 0.772 for the demand per household equation and 0.511 for the aggregate supply equation.

\section{Coefficient Estimates}

Table 2 reports unweighted 2SLS estimates for the renter households and rent adjustment equations, and autoregressive 2SLS estimates for the demand per household and aggregate supply equations. The demand per household, renter households, and rent adjustment equations are estimated exactly as specified in the model summary in Section II. The aggregate supply excludes the rent to user cost gap because of its inconsistent performance as discussed above.

All coefficients in the demand per household equation have the expected signs and are significant at the 5 percent level. The partial adjustment coefficient equals 0.604 , indicating that about 60 percent of the gap between current demand and its long-run equilibrium value is closed in one year, and about 95 percent after three years. The rental price elasticity of rental housing demand per household equals -0.705 in the short-run and -1.167 in the long-run. The short-run and long-run income elasticities equal 0.591 and 0.978 .

The demand for rental housing units equation also performs well, but reveals a considerably slower adjustment to long-run equilibrium than does services demand. The partial adjustment coefficient of 0.083 implies that only 8 percent of the gap between the current number of renters and the long-run equilibrium value is closed each year, and about 23 percent after three years. Increases in both the price of renting relative to owning and average household income reduce the number of renter households. The relative housing price elasticity equals -0.016 in the short- run and -0.193 in the long-run. The small relative price coefficient suggests that the 
housing price effects on tenure choice are rather modest. The hypothesis that an increase in rent and a decrease in the user cost of home ownership have the same impact on tenure choice is not rejected at standard significance levels. The short-run and long-run income elasticities are -0.111 and -1.337 . Their magnitudes imply that household income levels play a larger role in tenure choice than do relative housing prices. Their negative signs suggest a preference for home ownership that can be more readily satisfied as average household income increases. However, the relative price and income coefficients are significantly negative only at the 10 percent level.

Population growth increases the number of renter households modestly in the short- run and more than proportionately in the long-run. One percent growth in the adult population produces 0.134 percent short-run growth in the number of renter households and 1.614 percent long-run growth. At the sample means, this represents 1.657 million more people and 36,942 more renter households in the short- run and 444,964 more in the long-run. Again, the coefficient is significantly positive only at the 10 percent level.

As noted above, the rent to user cost gap performed poorly and is not included in the final specification of the supply equation. Lagged excess supply is retained, but its performance is modest. A 1 percent increase in last year's excess supply decreases current aggregate rental housing supply by 0.452 percent, but the t-statistic is only 1.156 . The coefficient on lagged aggregate supply equals 0.962 , which suggests that the aggregate stock of housing is slow to change.

The estimates of the rent adjustment equation indicate the importance of incorporating a rental price adjustment process into the structural model. The coefficient of the lagged rent to user cost ratio is -0.026 and significant. A 10 percent increase in user cost reduces the rate of 
growth of real rent by 0.26 percentage points. Similarly, the coefficient of lagged excess supply is -0.146 and significant. A 10 percent increase in excess supply reduces the rate of growth of real rent by 1.46 percentage points. ${ }^{12}$ Although the coefficients have the expected signs and provide a sense of the immediate response of real rent, by themselves they do not reveal much about the speed at which rent converges to its equilibrium value or even whether long-run equilibrium rent fully adjusts to a change in user cost. In order to address these issues, it is necessary to simulate the entire four equation model.

\section{Empirical Analysis of the Structural Model}

The empirical properties of the estimated model are evaluated in two ways. First, the stability of the model is assessed by examining the path to convergence of the endogenous variables. Second, the impact of a shock to rental user cost is determined. This latter experiment indicates the speed at which rent adjusts to a shock in user cost and shows the effects on other endogenous variables generated by such a shock.

To assess the stability of the model, all exogenous variables are held at their 1993 levels while the endogenous variables are forecast for 200 years. This exercise reveals the model does indeed converge. Aggregate supply increases from \$1,173 billion in 1993 to $\$ 1,279$ billion after 200 years, while aggregate demand increases from $\$ 1,086$ billion to $\$ 1,171$ billion. Most of the rise in aggregate demand results from the almost 6 percent increase in the number of renters from 34.7 million to 36.7 million. About 55 percent of the change in aggregate supply and aggregate demand occurs within the first five years, whereas about 25 percent of the change in the number of renter households is achieved. The path to convergence of real rent and demand per 
household is nonmonotonic. Real rent rises for four decades, but only by 1.6 percent, before declining modestly as it approaches its equilibrium value. The net effect is a 1.4 percent increase in real rent from $\$ 1,582$ to $\$ 1,605$. This value still falls well short of the 1993 user cost of $\$ 2,613$. Demand per household declines for about four decades, then rises to approach its equilibrium value. The net effect is an increase in demand per household from $\$ 31,306$ to $\$ 31,879$, or about 2 percent.

An important issue in analyzing the rental housing market is the speed and magnitude of the response of market rent to changes in the user cost of capital. Changes in rental user cost may be generated by a variety of factors, including interest rates, expected inflation and tax policy. The simulations conducted by HFL and FHL predicted that the Tax Reform Act of 1986 would generate a 10 percent increase in the user cost of rental housing capital. Based upon their assumptions regarding the nature of the rental housing market, they predict that market rents will also rise by 10 percent in the long-run. We investigate this process with our estimated model by assuming rental user cost rises by 10 percent in the initial year. The simulation results indicate that rent increases by 6 percent, but only after 200 years! Real rent increases very gradually in the initial years following the user cost shock, while the supply and demand variables decline over time. After five years, real rent is 1 percent higher and other endogenous variables are smaller by 1 percent or less. After ten years, real rent is 1.7 percent higher than initially, while the remaining system variables are smaller by 2 percent or less. Real rent is 4.7 percent higher after 50 years, but never equals user cost. Although rent does rise in response to a user cost shock, the adjustment process is indeed a very long one and the ultimate change is about half as large as that predicted by the standard user cost model. 
Although a detailed comparison of our results with those of DiPasquale and Wheaton (1992) is difficult because of several differences in variable definitions and model specification, a rough comparison is instructive. Both studies estimate similar magnitudes for the own price elasticity of the demand for rental housing. However, DiPasquale and Wheaton find a positive relationship between income and the demand for rental units, whereas we find a negative relationship between income and the demand for rental units and a positive income elasticity of housing demand per renter household. A simulation of our model reveals that a 10 percent increase in income produces a 2.2 percent decline in aggregate demand. Another and more important comparison pertains to the responsiveness of rent to a change in user cost. Both studies find a less than complete response of rent to a user cost shock triggered by a tax policy change, although the magnitudes of the responses differ markedly between them. We find a 60 percent response to the rise in user cost, and they find an 8 percent response. ${ }^{13}$

\section{Conclusions}

The primary purpose of this paper is to estimate a structural model of the rental housing market. The model distinguishes between housing units and housing services and permits an evaluation of the extent and speed with which real rent adjusts to a shock in the user cost of capital. The performance of the model is consistent with the theoretical structure discussed in Section II with one major exception. The rent to user cost of capital gap performs poorly in the supply equation and is excluded from the final specification of the model. Otherwise, the signs of the coefficients in the four equation model in Table 2 are as expected and most of the elasticity estimates seem reasonable, especially the estimates of the elasticities of the services and 
units demand equations. The long-run rental price and income elasticities of housing services demand equal -1.167 and 0.978 . The long-run elasticity of rental units demand is -0.193 for the relative rental to ownership price and -1.337 for income. Summing the income elasticities of services and units demand gives an income elasticity of aggregate demand of -0.359 .

The impact of a user cost shock on the level of rent is of primary interest. A 10 percent increase in user cost raises real rent by 6 percent; about 30 percent of this net impact is realized within the first decade after the user cost shock. Thus, the response of rent to a user cost shock is less than that predicted by the standard user cost model and the adjustment process is long and slow.

Another aspect of the results that sheds light on the validity of the standard user cost model is the route by which user cost affects rent. We expected to find most of the response reflected in the rental user cost coefficient in the supply equation, but because the rent to user cost gap performs poorly and is excluded from the supply equation, the only route by which user cost has a direct effect in the model is through the rent adjustment equation. Its presence in this equation produces a positive linkage between rent and user cost, though a sluggish one. An increase in user cost increases rent directly. Higher rent reduces housing demand and increases excess supply. The increase in excess supply directly reduces the supply of housing. However, because excess supply enters the rent adjustment equation negatively, it has a dampening effect upon the speed with which rent adjusts to the higher user cost.

The slow and less than complete response of rent to a user cost shock obtained here and by DiPasquale and Wheaton (1992) is at odds with the equilibrium assumption of long-run equality. We offer three broad explanations for this difference. First, perhaps supply is less 
elastic than is assumed in the HFL and FHL analysis. The long-run supply elasticity implicit in our model is 2.3 , which is obtained by comparing equilibrium solutions of the model before and after a demand shock, e.g., a 10 percent increase in income. This less than perfectly elastic supply function may reflect a substantial land component in the replacement cost of rental housing; presumably the supply of land is less than perfectly elastic. If so, then simulation models like those of HFL and FHL are likely to overestimate the response of rent to a change in user cost because they do not allow the long-run equilibrium price level to be affected by changes in demand.

Second, our measure of the user cost of capital may be flawed. However, since we use one commonly espoused in the literature, this casts doubt on a much broader set of measures than our own. At least two flaws seem possible. First, the use of a single discount rate may understate the importance of tax benefits and overstate the importance of expected capital gains. Second, tax policy may itself be endogenous, as FHL suggest. For example, builders may believe that Congress will alter tax policy if the market is either too strong or too weak. If so, then user cost will not be as volatile as our measure implies. Future empirical research exploring these two issues may prove fruitful.

The last and most likely explanation for the slow adjustment process reported in this paper relates to the data employed. In Section III, several potential weaknesses in the data used in this study are addressed; these include the aggregate nature of the data, the absence of an asset price index and, most importantly, the small sample size. Perhaps these weaknesses are simply too severe to permit identification of the link between real rent and user cost. A better understanding of the linkage may only be possible with more observations and by using data for smaller market 
areas like the metropolitan housing market. But even this approach is unlikely to settle the issue definitively owing to the complexity of the effects being examined and the severe data requirements. Nonetheless, efforts in this direction ought to be continued. 


\section{Endnotes}

1 This formulation assumes that new construction is completed in one period.

2 A more elaborate construction equation like (3) can be derived as the outcome of an intertemporal profit maximization problem as in Turnbull (1988). We use this simple specification because it is a quite common specification and because a more elaborate construction equation adds little to the central message of this paper.

3 It is apparent from equation (5) that the current asset price is a complex function that depends upon the manner in which expectations about the future gap between rent and replacement cost are formed. Alm and Follain (1994), DiPasquale and wheaton (1995), Mankiw and weil (1989) and others investigate various assumptions such as perfect foresight, adaptive expectations, and rational expectations. Testing these various models poses difficult econometric problems and strict data requirements. Nonetheless, Alm-Follain provide a formal justification for this proxy. They show that if rents follow a partial adjustment process, i.e., $\left(p r_{\underline{t}+1}-p r_{\underline{t}}\right)=(1-g)\left(p r_{\underline{t}}-p r_{\underline{t}-1}\right)$ where $g$ is the rate of adjustment parameter, then the asset price in equation (5) simplifies to $P R_{t}$ $=P R C_{\underline{t}}+(p r-u c r P R C)_{t-1} /(g+r)$.

4 We also experimented with variables suggested by an accelerator theory of investment like the rate of change in gross national product. These generally performed poorly and are excluded from the supply equation.

5 Follain, Leavens and Velz discuss some weaknesses associated with using metropolitan level data.

61993 values were provided by Michael Glenn of the Department of Commerce. The constant cost series is in 1987 dollars.

7 others have noted this bias and made similar adjustments. see Apgar et al. (1987) and DiPasquale and Wheaton (1992).

8 The key in the 1964-68 period is the recapture provision, which changed in 1969 to discourage multiple trading. FHL analyze the impact of multiple trading and show that user cost declines modestly if multiple trading is allowed. Although the allowance for multiple trading is appropriate and produces a modest change in the user cost series for these years, it has no impact upon the basic results in this paper. 
9 This price deflator is, with minor modifications, the same one used to deflate the commerce series on the value of the owneroccupied stock of housing. We use this rather than the price index used to generate the real value of the owner-occupied housing stock because we seek to measure the relative cost of renting and owning the same house. In fact, using this approach rather than the price index for owner-occupied housing makes no difference to our results.

10 If the null hypothesis of no autocorrelation is true, then Durbin's h-statistic is distributed as a standard normal in large samples. Durbin's $h$ equals -0.382 for the renter households equation and 0.786 for the rent adjustment equation so there is no empirical evidence to indicate the presence of autocorrelation. Durbin's $h$ equals 2.664 for the demand per households equation, so a correction for autocorrelation is necessary.

11 The t-statistic of 2.704 indicates that the coefficient of the lagged residual is significant at the 5 percent level. Thus, the null hypothesis of no autocorrelation is rejected for the aggregate supply equation.

12 To verify this specification, the equation is also estimated with an intercept and without imposing the restriction that the coefficient of lagged rent equals unity. The intercept estimate is not significantly different from zero and the coefficient of lagged rent is not significantly different from unity. This evidence is consistent with equation (6).

13 Dipasquale and wheaton assume that TRA increases user cost by four percentage points or, roughly, from 4 to 8 percent. Real rent rises by only 8 percent in response to this 100 percent increase in user cost. We simulate the effect of a 10 percent increase in real user cost, which is the estimate provided by both HFL and FHL in their analysis of TRA, and find that real rent rises by 6 percent. 


\section{References}

Alm, J., and J.R. Follain, "Shocks and Valuation in the Rental Housing Market," Journal of Urban Economics, 36, 117-142 (1994).

Apgar, W.C., R. Peng, and J. Olson, "Recent Trends in Real Rents," Working Paper No. W87-5, Joint Center for Housing studies, Cambridge, MA (1987).

DiPasquale, D. and W.C. Wheaton, "The Cost of Capital, Tax Reform, and the Future of the Rental Housing Market," Journal of Urban Economics, 31, 337-359 (1992).

, The Economics of Real Estate Markets, Englewood Cliffs: Prentice Hall, Englewood Cliffs, NJ (1995)

Fair, R.C., "The Estimation of Simultaneous Equation Models with Lagged Endogenous Variables and First order serially Correlated Errors," Econometrica, 38, 507-516 (1970).

Follain, J.R., P.H. Hendershott, and D.C. Ling, "Understanding the Real Estate Provisions of Tax Reform: Motivation and Impact," National Tax Journal, 3, 363-372 (1987).

Follain, J.R., D.R. Leavens, and O.T. Velz, "Identifying the Effects of Tax Reform on Multifamily Housing," Journal of Urban Economics, 34, 275-298 (1993).

Follain, J.R. and D.C. Ling, "Another Look at Tenure Choice, Inflation, and Taxes," Journal of the American Real Estate and Urban Economics Association, 16, 227-229 (1988).

Greene, W.H., Econometric Analysis, 2nd ed., New York: Macmillan Publishing Co. (1993).

Hendershott, P.H., "Rental Adjustment and Valuation of Real Estate in Overbuilt Markets: Fundamental Versus Reported office Market Rents in Sydney, Australia," Journal of Urban Economics, _ _ _ (1995).

Hendershott, P.H., J.R. Follain, and D.C. Ling, "Effects on Real Estate," in: Joseph A. Pechman, ed. , Tax Reform and the U.S. Economy. Washington, DC: The Brookings Institution (1987).

Kmenta, J., Elements of Econometrics, 2nd ed., New York: Macmillan Publishing Co. (1986). 
Ling, D.C., "Real Estate Values, Federal Income Taxation, and the Importance of Local Market Conditions," Journal of the American Real Estate and Urban Economics Association, 20, 125-140 (1992).

Mankiw, N.G. and D.N. Weil, "The Baby Boom, the Baby Bust, and the Housing Market," Regional Science and Urban Economics, 19, 235-258 (1992).

Musgrave, J., "Fixed Reproducible Tangible Wealth in the United States, Revised Estimates for 1990-1992 and Summary Estimates for 1925-1992," Survey of Current Business, Sept., 61-69 (1993).

Ozanne, L., "Expanding and Improving the CPI Rent Component," in: John Tuccillo and Kevin Villani, eds., House Prices and Inflation, Washington, DC: The Urban Institute Press (1981).

Poterba, J., "Tax Subsidies to Owner-Occupied Housing: An Asset-Market Approach," Quarterly Journal of Economics, 99, 729-752 (1984).

Turnbull, G.K., "Market Structure, Location Rents, and the Land Development Process," Journal of Urban Economics, 23, 261-277 (1988). 
Table 1: Descriptive Statistics

\begin{tabular}{llcc}
\hline \multicolumn{1}{c}{ Name } & \multicolumn{1}{c}{ Description* } & Mean & $\begin{array}{c}\text { Standard } \\
\text { Deviation }\end{array}$ \\
\hline$q$ & Rental Quantity per HH & $\$ 29,507$ & $\$ 2,917$ \\
$N R$ & Number of Renters (thousands) & 27,569 & 4,691 \\
$Q S$ & Real Aggregate Rental Supply (\$bill) & $\$ 880.40$ & $\$ 220.25$ \\
$Q D$ & Real Aggregate Rental Demand (\$bill) & $\$ 824.12$ & $\$ 203.29$ \\
$Q S-Q D$ & Excess Rental Supply (Sbill) & $\$ 56.28$ & $\$ 19.21$ \\
$p r$ & Real Rent (\$) & $\$ 1,507.28$ & $\$ 86.34$ \\
$p g d p$ & GDP Deflator (1987=100, SA) & 0.685 & 0.326 \\
$Y P$ & Real Consumption per HH (dollars) & $\$ 30,898$ & $\$ 2,660$ \\
$u c o$ & Owner User Cost Rate (percent) & $4.41 \%$ & $1.17 \%$ \\
$u c r$ & Rental User Cost Rate (percent) & $8.82 \%$ & $3.54 \%$ \\
$P O$ & Real Asset Price of Owner Housing (dollars) & $\$ 23,746$ & $\$ 1,618$ \\
$u c o ~ P O$ & Real Owner User Cost (dollars) & $\$ 1,048.87$ & $\$ 297.11$ \\
$u c r ~ P R C$ & Real Rental User Cost (dollars) & $\$ 2,235.12$ & $\$ 965.46$ \\
$p r-(u c r P R C)$ & Real Rent-User Cost Gap (dollars) & $-\$ 727.83$ & $\$ 962.89$ \\
$P R C$ & Real Replacement Cost of Apartment & $\$ 25,152.55$ & $\$ 1,530.00$ \\
$P O P$ & Adult Population ( $\geq 16$ yrs. mill) & 165.704 & 21.949 \\
\hline
\end{tabular}

${ }^{2}$ Real values are expressed in constant 1987 dollars. 
Table 2: 2SLS Estimates of a Rental Housing Market Model

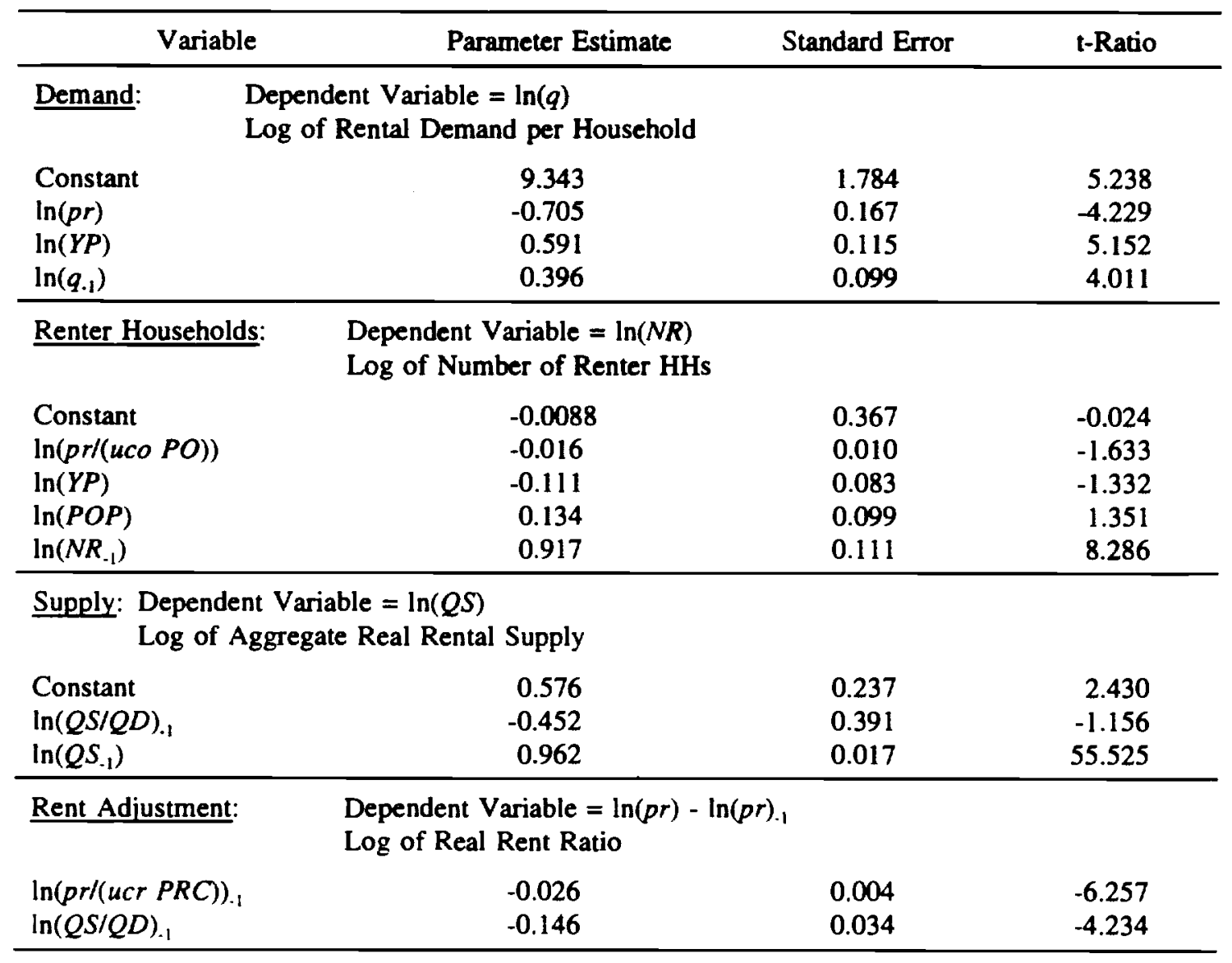


MF Starts and Change in Stock

Figure 1

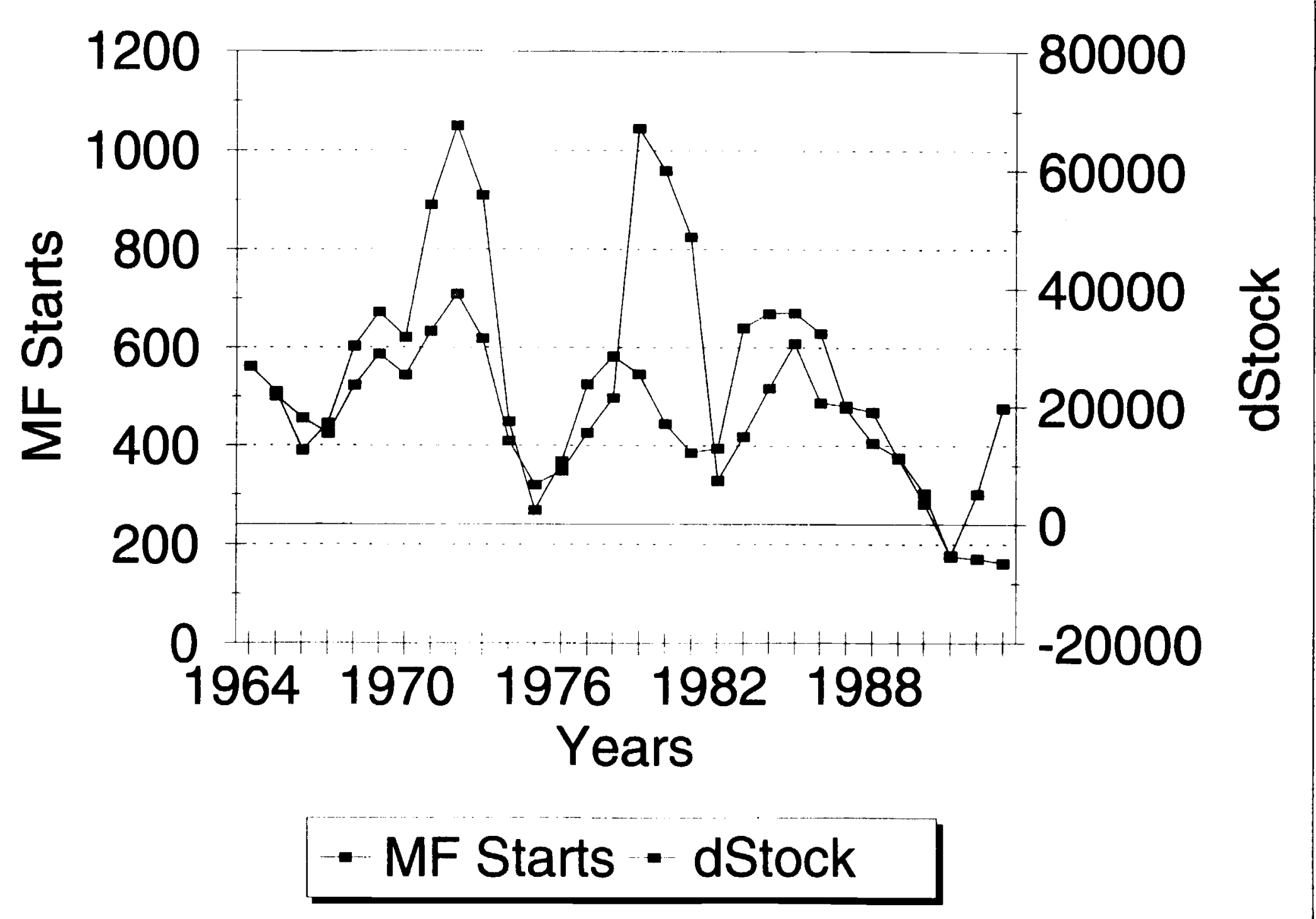




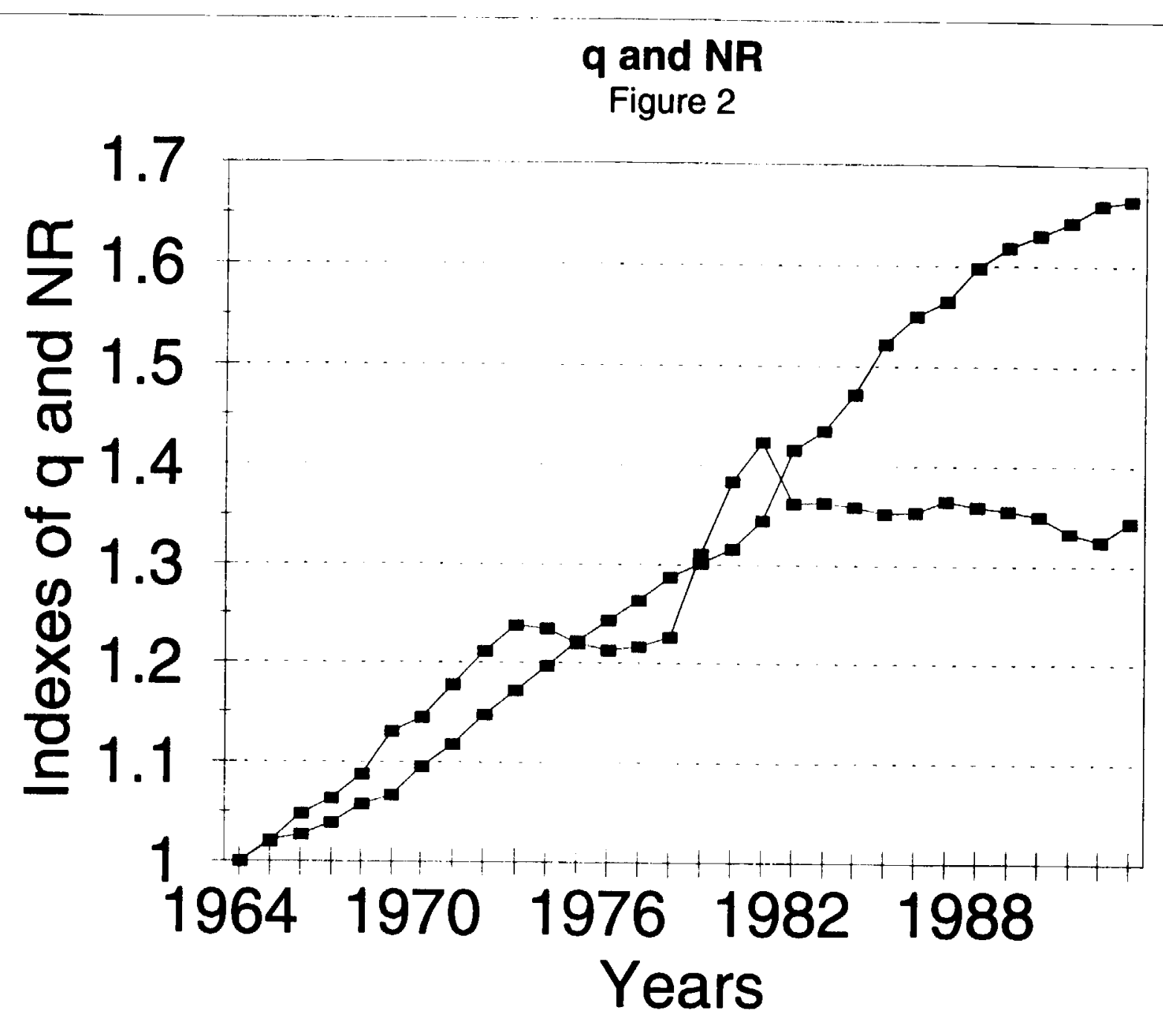

- Housing per Renter Household (q)

- Renter Households (NR) 


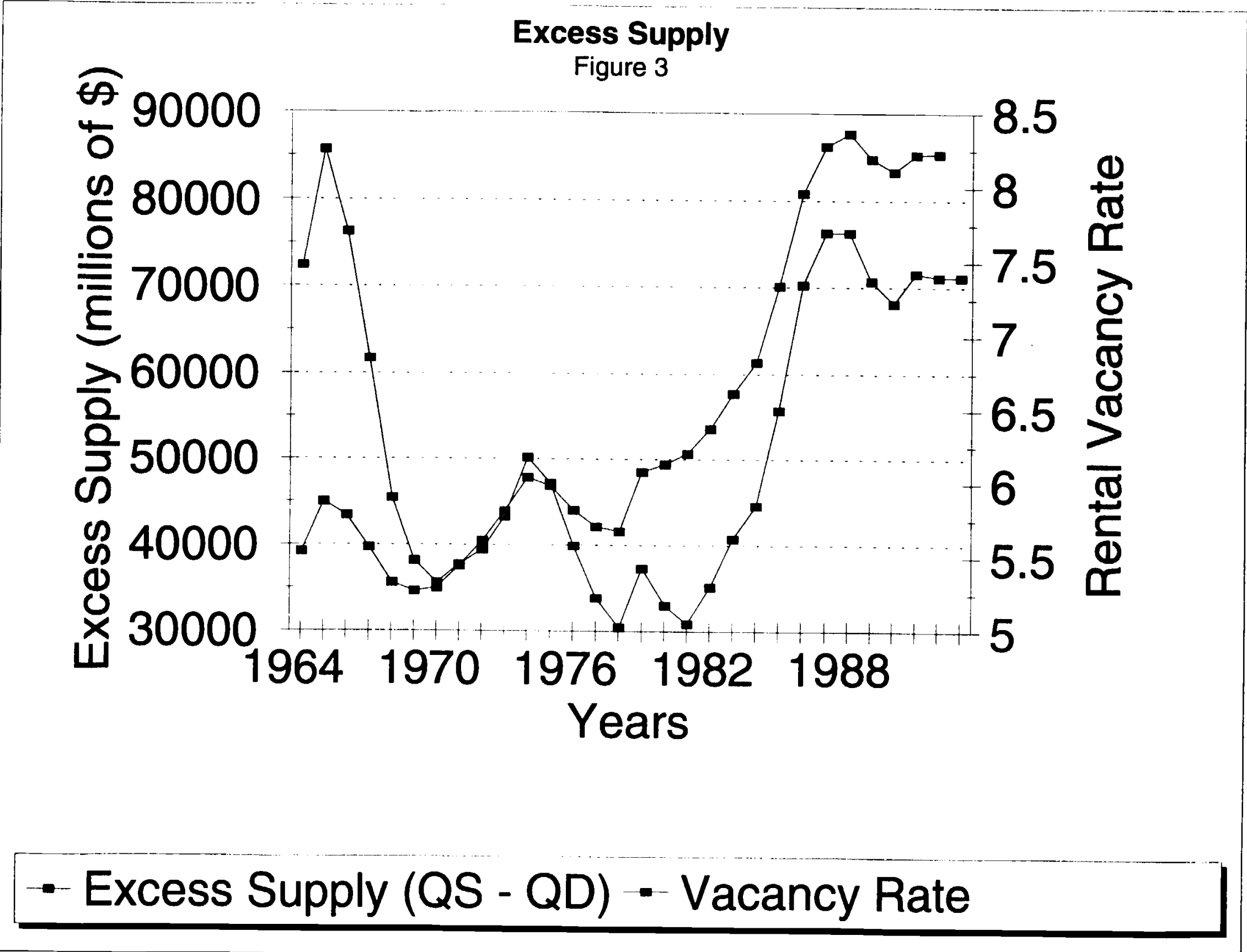




\section{Rent and User Cost}

Figure 4

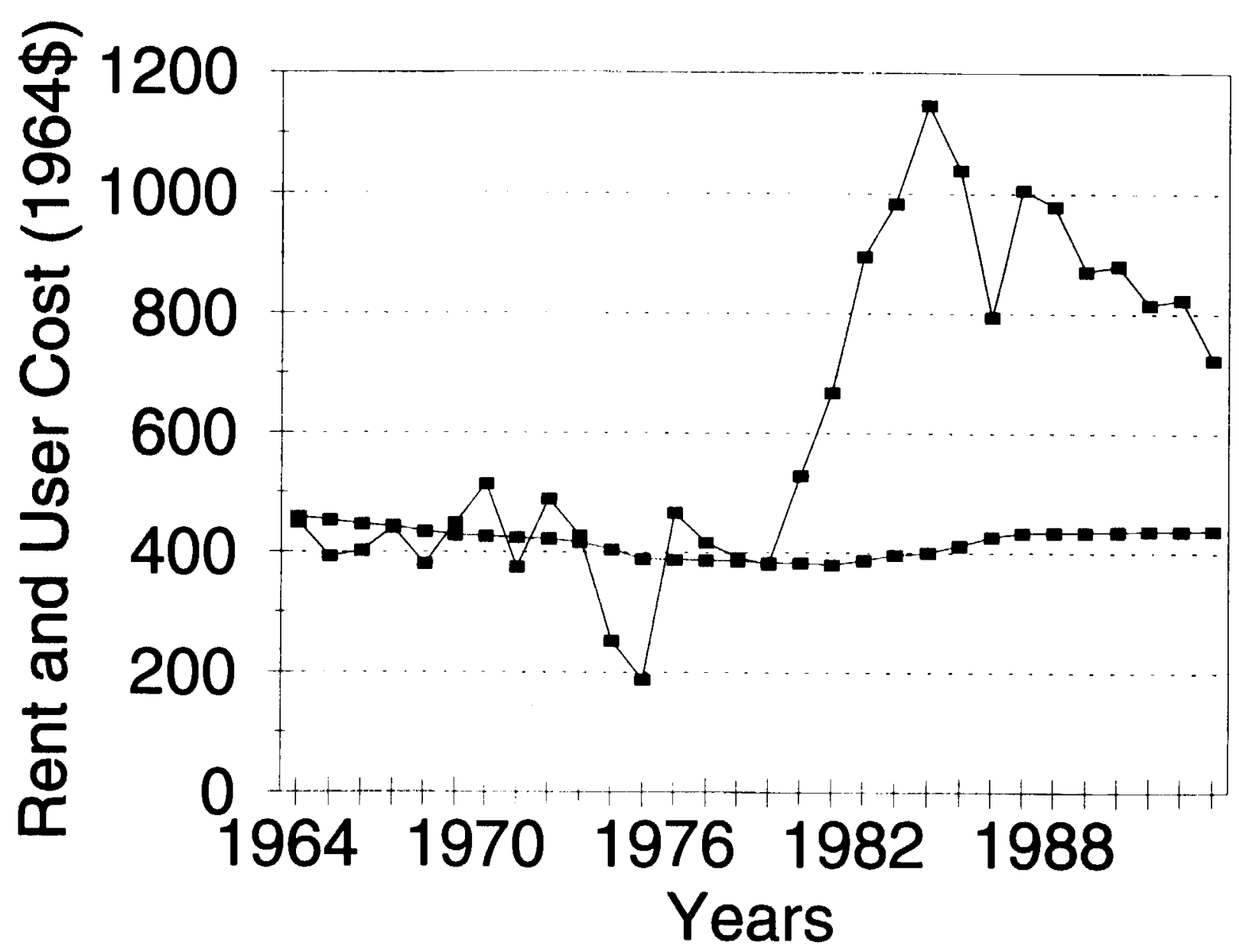

- User Cost - Rent 


\section{Rent - User Cost Gap}

Figure 5

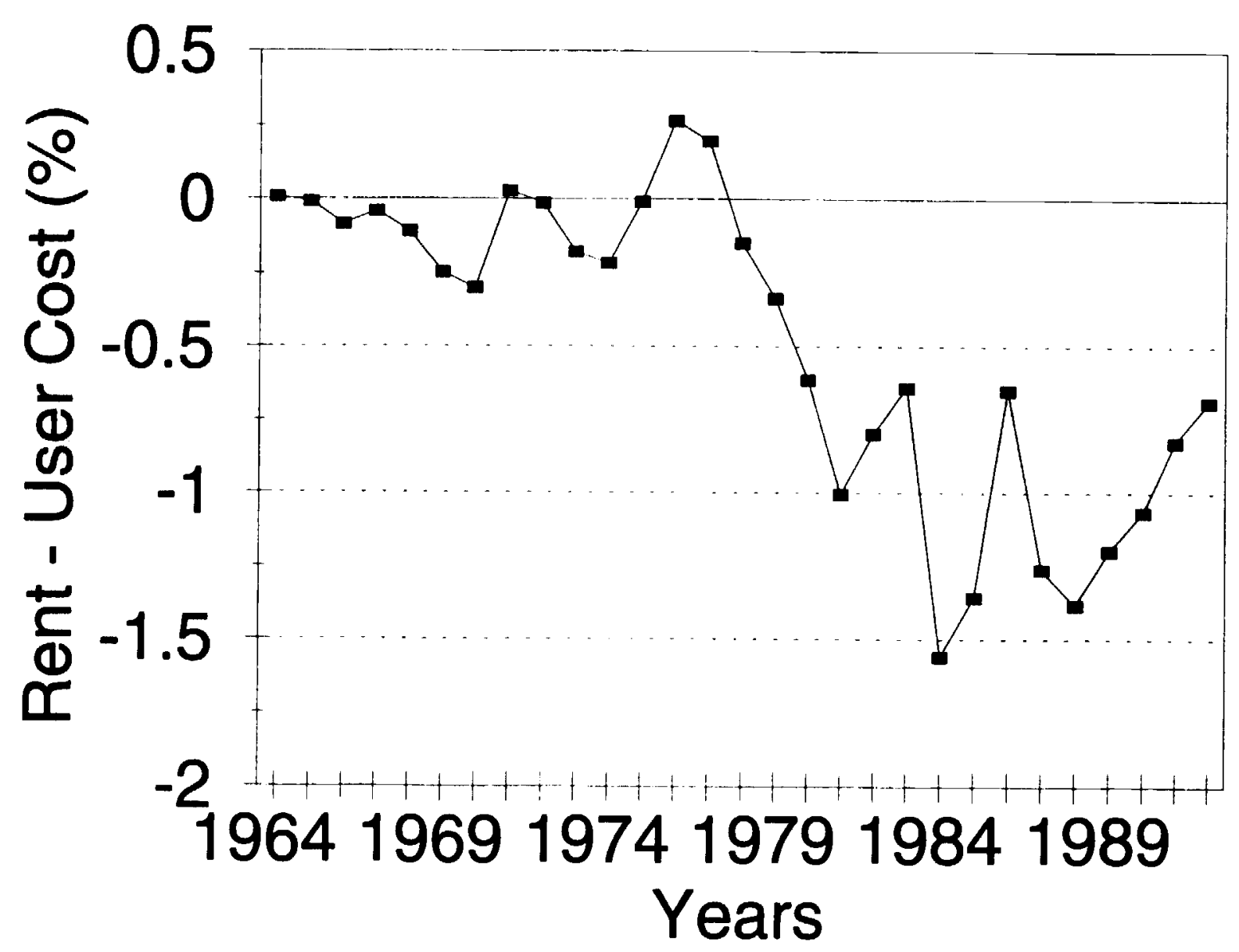

